\title{
Bibliometric analysis of publications related to the term 'servitization' in operations management
}

Priscila Bresolin Tissot ${ }^{1}$ - Univ. de Caxias do Sul - Prog. de Pós-Graduação em Administração - Centro de Ciênc. Sociais Vilmar Antonio Gonçalves Tondolo² - Univ. Fed. do Rio Grande - Prog. de Pós-Graduação em Administração - Instituto de Ciências Econônicas, Administrativas e Contábeis

André Espíndola³ - Univ. de Caxias do Sul - Programa de Pós-Graduação em Administração - Centro de Ciências Sociais André Andrade Longaray 4 - Univ. Fed. do Rio Grande - Prog. de Pós-Graduação em Administração - Instituto de Ciências Econônicas, Administrativas e Contábeis

Maria Emília Camargo 5 - Univ. de Caxias do Sul - Prog. de Pós-Graduação em Administração - Centro de Ciênc. Sociais

ABSTRACT The term servitization has been used since the 1980s to explain the phenomenon of integration of services to products as an organization's business strategy. After nearly three decades of its definition, the servitization is still a concept with gaps to be defined. This article aims to describe the panorama of scientific literature on the term 'servitization'. With respect to the procedures adopted, we used the technique of bibliometrics, held in Scopus Database, between January 1988 and July 2015. Among the main results, it was found that a significant number of studies on the subject was held in European countries, involving 37 journals and 155 researchers from 22 countries. With respect to the methods and techniques used, it was possible to identify the prevalence of qualitative methods such as the case study. The keywords allowed identifying new terms, similar to servitization. In addition, it was revealed the absence of studies that consider servitization from the perspective of the end user.

Keywords: Strategy. Servitization. Bibliometry. 


\section{INTRODUCTION}

The term servitization was developed in 1988 by Sandra Vandermerwe and Juan Rada, in their article 'Servitization of Business: Adding Value by Adding Services'. Since then it has been employed as a business strategy feature where services are integrated into products by companies that previously were only manufacturing. Contemporary companies have modified their style of operation and sought to offer its customers complete solutions within its market, with combinations of goods, services, support and knowledge (VANDERMERWE; RADA, 1988).

Whereas this process is described by Vandermerwe and Rada (1988) as an evolutionary process, the interest in this topic tends to increase, in order to explain the new relationships in the market. In order to carry out in-depth research on this subject is necessary, at first, understand the theoretical work published so far. According to a survey conducted by Baines et al. (2009a), by the end of the first decade of this millennium, there were about 60 articles published trying to understand the definition of servitization, while 90 other research dealt with similar themes. However, the contributions of each study, whether theoretical or of management, had not been identified, giving rise to new studies in the area.

According to the authors, it is necessary to understand that the concept of servitization cannot be understood as universally applicable, and that the sectors that have implemented the servitization and succeeded need to be identified in order to build a solid foundation for companies (BAINES et al., 2009b). In this context, this article aims to describe the panorama of scientific literature on the term 'servitization', identifying the journals and authors with the highest number of publications, as well as the analysis of sectors used in the area of operations. Therefore, we used a survey in Scopus Database, with data collected in July 2015.

In addition to this introductory section, Section 2 defines, characterizes and contextualizes the servitization as a business strategy. Section 3 discusses the technique of bibliometrics, its laws and operationalization. In Section 4, the methodological procedures adopted in the research are described. Section 5 presents the analysis of the results of the work. Finally, section 6 sets out the final considerations. 


\section{SERVITIZATION AS A BUSINESS STRATEGY}

\subsection{Definition of servitization}

The term servitization was developed in the 1980s and since then it has been widely used by companies worldwide (BAINES et al., 2009a). In the past, executives of large manufacturing companies positioned themselves contrary to a change to include services in their products, as they did not have the necessary skills, besides thinking it was a high cost to be added to the price of products. However, over time, companies began to seek new ways to gain and maintain competitive advantage, changing the dynamics of relationships and vision about their own business (VANDERMERWE; RADA, 1988).

Servitization can be understood as the process of creating value adding services to products (BAINES et al., 2009a; VANDERMERWE; RADA, 1988). This process is accomplished by offering complete packages to the customer, including combinations of goods, services, support, self-service and knowledge, in order to add value to the assets (VANDERMERWE; RADA, 1988). It is importante to notice that, for Vandermerwe and Rada (1988), services should be understood as something performed and not produced, being essentially intangible.

According to Schmenner (2009), supply chains, in the way they are established, have been a mixture of manufacturing and services for more than 150 years, however, before the 1850s these stages were carried out by different economic actors. With the passage of time and seeking sustainable competitive advantages in organizations, companies went through three different evolutionary stages in order to integrate the activities of its production chain, being: (i) stage one: products or services; (ii) stage two: products and services; (iii) stage three: products, services, support, knowledge, and self-service (VANDERMERWE; RADA, 1988).

From this evolutionary process, it is understood that, in principle, organizations perceived goods and services as different fields and companies chose in which they wished to act. With the advancement of technology and other converging trends, these definitions have changed and companies understood that products and services would be often inseparable, which caused the move to the second stage, where products and services would be understood as inseparable. The third evolutionary stage understands that to gain competitive advantage you need that business is focused on the customer and thus, companies offer "packages" formed by the combination of products, services, support, self-service and knowledge (VANDERMERWE; RADA, 1988). 
Authors such as Pawar et al. (2009) describe the servitization process as the phenomenon that results in the provision of complex packages of products and services by organizations, in order to generate benefit for consumers and thus increase competitive advantage. This behavior within the literature on product-service systems, is understood as the transition from pure product and pure supply of services (SMITH; MAULL; NG, 2014).

According to the Tellus Institute (1999), servitization means the emergence of a new organization of product-based services, in which the distinction between manufacturing and tradicional service sector activites is modified. At the same time, according to Baines et al. (2009a), page 555, "servitization is the innovation of an organisations capabilities and processes to better create mutual value through a shift from selling product do selling PSS".

\subsection{Terms related to servitization}

By studying the literature on the paradox of servitization, other nomenclatures appear with similar definitions. The main term related to servitization is, certainly, product-service systems, or PSS, although this definition should consider servitization as a specific type or product-service offering (BAINES et al., 2009a). To Eloranta and Turunen (2015), for example, the act of offering solutions integrating product and service, with guidance for the consumer, is called 'service infusion'.

Moreover, the line between the distinction between product-service system; servitization; outsourcing; among others is tenuous and therefore may be subject to different interpretations (JIANG; LI; ZHANG, 2009). According to the research conducted by Baines et al. (2009a), the terms related to servitization may include the service business expansion, solutions provision, after-sales marketing, and service profitability, and the term "servitization" appears only in the papers that offer a definition.

Overall, there are four concepts that are often confused with each other, and are related to servitization, namely: (i) the product-service system; (ii) servitization; (iii) servitizated organizations that support product-service systems and ; (iv) the overall value system that supports the product-service system (NEELY, 2009). From this concept, the product-service systems are understood as 
integrated product offering and service that adds value to its use (NEELY, 2009) innovating and creating ever more sophisticated $\backslash$ nproducts and services, so they do not have to compete on the basis of cost.|nWhile this strategy is proving increasingly popular with policy makers and $\backslash$ nacademics there is limited empirical evidence to explore the extent to which it $\backslash n$ is being adopted in practice. And if so, what the impact of this servitization/nof manufacturing might be. This paper seeks to fill a gap in the literature by\npresenting empirical evidence on the range and extent of servitization. Data arelndrawn from the OSIRIS database on 10,028 firms incorporated in 25 different $\backslash$ ncountries. The paper presents an analysis of these data which suggests that: [i] \nmanufacturing firms in developed economies are adopting a range of servitization $\backslash$ nstrategies $\backslash u 201412$ separate approaches to servitization are identified; [ii] these $12 \backslash$ ncategories can be used to extend the traditional three options for $\mid$ nservitizationlu2014product oriented Productlu2013Service Systems, use oriented $\backslash$ nProduct $\backslash$ u2013Service Systems and result oriented Productlu2013Service Systems, by adding $\backslash$ ntwo new categories \u201cintegration oriented Product|u2013Service Systemslu201d and |u201cservicelnoriented Product|u2013Service Systems\u201d; [iii] while the manufacturing firms that havelnservitized are larger than traditional manufacturing firms in terms of sales\nrevenues, at the aggregate level they also generate lower profits as a \% of \nsales; [iv] these findings are moderated by firm size (measured in terms of $\backslash$ nnumbers of employees.

In another form, the servitization involves the innovation of capacities and processes of an organization in order to increase the creation of mutual value through a change of product sales for the product-service systems. In the same way, servitizated organizations draw, build and deliver one or more product offerings and integrated services that add value to their use (NEELY, 2009)innovating and creating ever more sophisticated $\backslash$ nproducts and services, so they do not have to compete on the basis of cost.InWhile this strategy is proving increasingly popular with policy makers and $\backslash$ nacademics there is limited empirical evidence to explore the extent to which it $\backslash$ nis being adopted in practice. And if so, what the impact of this servitization/nof manufacturing might be. This paper seeks to fill a gap in the literature by\npresenting empirical evidence on the range and extent of servitization. Data arelndrawn from the OSIRIS database on 10,028 firms incorporated in 25 different $\backslash$ ncountries. The paper pre- 
sents an analysis of these data which suggests that: [i] $\backslash$ nmanufacturing firms in developed economies are adopting a range of servitization $\backslash n$ strategies\u201412 separate approaches to servitization are identified; [ii] these $12 \backslash$ ncategories can be used to extend the traditional three options forlnservitizationlu2014product oriented Productlu2013Service Systems, use oriented $\backslash$ nProduct|u2013Service Systems and result oriented Productlu2013Service Systems, by adding $\backslash$ ntwo new categories \u201cintegration oriented Product $\mid u 2013 S e r v i c e$ Systemslu201d and |u201cservicelnoriented Productlu2013Service Systems\u201d; [iii] while the manufacturing firms that havelnservitized are larger than traditional manufacturing firms in terms of sales $\backslash$ nrevenues, at the aggregate level they also generate lower profits as a \% of $\backslash$ nsales; [iv] these findings are moderated by firm size (measured in terms of $\backslash$ nnumbers of employees.

The global value systems, in turn, constitute the network (globally established) of of suppliers, customers and partners who need to cooperate to ensure that the integrated products and services will add value to their use (NEELY, 2009). This way, on further analysis, you can understand that servitization not only is the product offering and integrated service, but rather an integrated offering that has the objective of adding value and thus increase the performance and competitiveness of the company.

\subsection{Implications from Servitization}

According to Neely (2009), the servitization paradox is influenced by firm size and local economic circumstances, where larger firms tend to servitize more than smaller firms (measured through number of employees and revenues). In this context, this study allowed to understand that while servitized firms generate higher revenues to the companies, they tend to generate lower net profits than pure manufacturing firms, because the servitized firms have higher average labour costs, assets and working capital.

Still in terms of economic performance, a survey conducted in Zhejiang Province, China, in 2015, showed that there is a significant positive relationship between servitization and the economic performance of manufacturing companies. In addition, this study allowed the understanding that the servitization process is more suitable for large enterprises (LI et al., 2015). Thus, the study presents a favorable outlook for the development of new research related to the topic. 
However, it is important to note that the research presented another intriguing result, with regard to investment in human resources, showing that, to promote servitization, greater investment in human resources in organizations is necessary. According to the authors, the impact of servitization in the economic performance of companies depends on the degree of investment in the appreciation of human resources. That is, for companies to be profitable through servitization you need to invest in human resources, which, in the same way, can create more employment opportunities in society (LI et al., 2015).

In this sense, despite the paradox of servitization have been developed and continue to develop in the industrialized countries, generating competitive advantage for businesses, the issue also arises as a opportunity for emerging countries, which can not only increase the income of their organizations, but also increase the supply of jobs and improve the quality of life of the population.

In the last few years, the literature began to associate the servitization paradox to the knowledge management systems, highliting the importance to create a system to support the servitization strategy in a manufacturing firm (LEONI, 2015; OPRESNIK; TAISCH, 2015). The findings from Opresnik and Taisch (2015), page 182, indicates that, "the more a manufacturing enterprises servitizes its products, the more users they have, the more data can be collected and information exploited through resell and/or reuse". This way, big data exploitation should be considered as the next step of the value creation in the servitization process.

On the other hand, Leoni (2015) established five connections between servitization and knowledge management, through a case study at IBM Corporation. These connections are: (i) adding service means adding knowledge and becoming a "squint company"; (ii) integrate withouth melting; (iii) KM systems follows business strategy and web opportunities; (iv) social perspectives and information network and; (v) encourage knowledge sharing. In general, this paper suggests that changes in the knowledge management system are directly related to the adoption of a servitization strategy, establishing the relation between knowledge management and operations management (LEONI, 2015). 


\section{THE BIBLIOMETRIC ANALYSIS}

The bibliometric analysis or bibliometric research can be classified as a quantitative and statistic technique, since use of mathematical and statistical methods to quantify the production, dissemination and use of previously recorded information (FONSECA, 1986; CALDAS; TINOCO; CHU, 2003). Pritchard popularized the term bibliometry in 1969 , and the technique was created to meet the need to study and evaluate the scientific production activities (TAGUESUTCLIFFE, 1992).

The bibliometric analysis technique is developed from three empirical laws about the behavior of literature: the method of productivity measurement of scientists of Lotka, dated 1926; the Law of Scientific Knowledge Dispersion of Bradford, 1934; and the Model of Distribution and Word Frequency in a text of Zipf, dated 1949 (TAGUESUTCLIFFE, 1992).

Lotka Law is derived from a study regarding the productivity of scientists, taking into consideration the count of the authors present in Chemical Abstracts between 1909 and 1916. Thus, Lotka found that a small number of authors produces a large part of the scientific literature and a large number of small producers end up equaling, in production, to the small number of large producers. Lotka then formulated the Law of Inverse Square, which says that $\mathrm{yx}=6$ / p2 $\mathrm{xa}$, where $\mathrm{yx}$ is the frequency of authors publishing $\mathrm{x}$ number of papers and a is a constant value for each scientific field. However, many authors have found problems in the Lotka Law, and, over time, its lost strength (ARAÚJO, 2006).

The second bibliometric law, the Law of Bradford, concerns about the set of journals. According to Araújo (2006), the Bradford studies had the intention to identify the quantity of items of a particular scientific topic that appeared in journals aimed at other issues. From this research he formulated, then the Dispersion Law. Bradford found that there were many journals in the outer zone, or in journals aimed at other issues, and therefore, the indices did not reach full coverage of topics. In fact, more than half of all articles were not being considered in indexing and abstracts services. This law was widely used in libraries to assist in decisions about acquisition, binding, use of funds, among others. Nowadays the Bradford's Law is used in order to identify the most productive journals cores in a particular area (COOPER; BLAIR; PAO, 1993). 
The third Bibliometric law, Zipf's Law, lists the keywords and the classification of a document in a particular area, identifying the overall frequency of each word and multiplying it by the order of magnitude in which they appear in the text (TAGUESUTCLIFFE, 1992). According to Araújo (2006), when analyzing the work Ulysses of James Joyce, Zipf found that there was a correlation between the number of different words and their frequency of use, which allowed it to conclude that there is a regularity in the choice and use of words, by having a small number of words being used most often.

Thus, if the words that occur in a text were listed in descending order of frequency, the position of a word in the list multiplied by its frequency is equal to a constant, whose equation is: $: \mathrm{r} \mathrm{x} \mathrm{f}=\mathrm{k}$, where $\mathrm{r}$ is the word position, $\mathrm{f}$ is its frequency and $\mathrm{k}$ is a constant. The Zipf's Law was then enunciated as the Law of Least Effort, suggesting the existence of an economy in the use of words. As the trend is to use the least, it means that the words will not disperse, i.e., the same word will be used many times. Thus, the most used words indicate the subject of the document (ARAÚJO, 2006).

Although there are other currents in the bibliometric field, today, bibliometrics uses, in large part, the citation analysis. According to Araújo (2006), this analysis points to a number of standards related to scientific knowledge, such as the most cited authors, more productive, the impact factor of the authors and journals, geographic origin of the authors, most used types of document, obsolescence of literature, elite research, among others.

Moreover, trough a bibliometric analysis, it is possible to understand and identify the impact factor of the authors and journals. With regard to the authors, "the impact factor is the division of the number of citations received by an author divided by the number of works that received at least one citation" (ARAÚJO, 2006, p. 19). This index aims to identify the authors who, despite having little scientific production, produced significant material. The use of the impact factor to evaluate the production is common and current and therefore deserve attention in any field of knowledge (MEADOWS, 1999).

\section{METHODOLOGICAL PROCEDURES}

The method applied in this study has a quantitative approach and applied nature, which can be considered exploratory and descriptive regarding its objectives and regarding the procedures, it can be considered a documentary or bibliographic research. With respect to exploratory and descriptive purposes, 
according to Malhotra (2011), exploratory research is aimed at achieving ideas and information about a problem, it means, to exploit the situation of a problem when there are few previous information about this. Furthermore, this kind of search is conducted from a small sample and therefore must be considered as a starting point for further research. In other way, the descriptive research intendes to describe the characteristics of a given phenomenon. It is used to identify and obtain information about the characteristics of a given problem.

In relation to the search procedure, it is understood that the line between documentary research and literature review is tenuous and, for some authors, there are more similarities than differences between them. Taking into consideration that this study is a bibliometric research, the procedure os literature review was considered. Furthermore, concerning the Bibliometric Law, for purposes of this study, it was used the model of distribution and frequency of words in a text of Zipf, also known as Zipf's Law.

It was chosen as the unit of analysis the Scopus database, which, according to Elsevier (2015) is the largest reference source of technical and scientific literature reviewed by peers. The term defined for the research was 'servitization', seeking from the title, abstract and keywords (Article title, Abstract, Keywords). The search with the term 'servitization' in Portuguese produced no results.

In order to refine the search and identify only the items related to the area of Operations Management, the research was limited to the area of Social Sciences and Humanities, and later to the area of Business, Management and Accounting. Still, there were selected only articles published in journals. The search identified 67 articles published from 1988 to July 2015, whose titles, abstracts and keywords were analyzed in order to identify the overall frequency of each word, as well as other aspects related to the identified articles.

In addition, the same search was replicated in the site of 'Journal of Operations Management', one of the most important journals of the Operations Management area with an $\mathrm{H}$ factor of 122 (SCIMAGO JOURNAL \& COUNTRY RANK, 2015). However, the search returned only one result, and this had been included in the scope of this article by the previous search. Data collection was conducted from 1st to 15th July 2015. The analysis was conducted in July and August 2015. 


\section{ANALYSIS AND INTERPRETATION OF RESULTS}

The research, searching for from titles, abstracts and keywords generated 67 results, which were organized by number of citations and analyzed as follows. Table 1 shows the number of citations per paper, and the seminal article, written by Sandra Vandermerwe and Juan Rada, is the most cited article, with 373 citations. Three articles published in 2009 have, respectively, 190, 175 and 82 citations. Considering the cutoff point of 15 articles, the article with less number of citations, dated from 2013, has 10 citations.

Table 1 - Number of citation per work.

\begin{tabular}{|c|c|c|c|c|}
\hline ARTICLE TITLE & SOURCE & AUTHORS & YEAR & CITATION \\
\hline $\begin{array}{l}\text { Servitization of business: } \\
\text { Adding value by adding services }\end{array}$ & $\begin{array}{l}\text { European } \\
\text { Management } \\
\text { Journal }\end{array}$ & $\begin{array}{l}\text { Vandermerwe S., } \\
\text { Rada J. }\end{array}$ & 1988 & 373 \\
\hline $\begin{array}{l}\text { The servitization of manufacturing: } \\
\text { A review of literature and } \\
\text { reflection on future challenges }\end{array}$ & $\begin{array}{l}\text { Journal of } \\
\text { Manufacturing } \\
\text { Technology } \\
\text { Management }\end{array}$ & $\begin{array}{l}\text { Baines T. S., } \\
\text { Lightfoot H. W., } \\
\text { Benedettini O., } \\
\text { Kay J. M. }\end{array}$ & 2009 & 190 \\
\hline $\begin{array}{l}\text { Exploring the financial } \\
\text { consequences of the servitization } \\
\text { of manufacturing }\end{array}$ & $\begin{array}{l}\text { Operations } \\
\text { Management } \\
\text { Research }\end{array}$ & Neely A. & 2009 & 175 \\
\hline $\begin{array}{l}\text { Towards an operations } \\
\text { strategy for product-centric } \\
\text { servitization }\end{array}$ & $\begin{array}{l}\text { International } \\
\text { Journal of Operations } \\
\text { and Production } \\
\text { Management }\end{array}$ & $\begin{array}{l}\text { Baines T., } \\
\text { Lightfoot H., } \\
\text { Peppard J., } \\
\text { Johnson M., } \\
\text { Tiwari A., } \\
\text { Shehab E., } \\
\text { Swink M. }\end{array}$ & 2009 & 82 \\
\hline $\begin{array}{l}\text { Challenges in transforming } \\
\text { manufacturing organisations } \\
\text { into product-service providers }\end{array}$ & $\begin{array}{l}\text { Journal of } \\
\text { Manufacturing } \\
\text { Technology } \\
\text { Management }\end{array}$ & $\begin{array}{l}\text { Martinez V., } \\
\text { Bastl M., } \\
\text { Kingston J., } \\
\text { Evans S. }\end{array}$ & 2010 & 61 \\
\hline $\begin{array}{l}\text { Manufacturing, service, } \\
\text { and their integration: } \\
\text { Some history and theory }\end{array}$ & $\begin{array}{l}\text { International } \\
\text { Journal of Operations } \\
\text { and Production } \\
\text { Management }\end{array}$ & Schmenner R. W. & 2009 & 45 \\
\hline
\end{tabular}




\begin{tabular}{|c|c|c|c|c|}
\hline ARTICLE TITLE & SOURCE & AUTHORS & YEAR & CITATION \\
\hline $\begin{array}{l}\text { Services growth options for B2B } \\
\text { product-centric businesses }\end{array}$ & $\begin{array}{l}\text { Industrial Marketing } \\
\text { Management }\end{array}$ & $\begin{array}{l}\text { Raddats } C . \\
\text { Easingwood } C \text {. }\end{array}$ & 2010 & 33 \\
\hline $\begin{array}{l}\text { Product-service systems: } \\
\text { A literature review on integrated } \\
\text { products and services }\end{array}$ & $\begin{array}{l}\text { Journal of } \\
\text { Cleaner } \\
\text { Production }\end{array}$ & $\begin{array}{l}\text { Beuren F. H., } \\
\text { Gomes Ferreira M. G., } \\
\text { Cauchick Miguel P. A. }\end{array}$ & 2013 & 23 \\
\hline $\begin{array}{l}\text { Servitization: Disentangling } \\
\text { the impact of service business } \\
\text { model innovation on } \\
\text { manufacturing firm performance }\end{array}$ & $\begin{array}{l}\text { Journal of } \\
\text { Operations } \\
\text { Management }\end{array}$ & $\begin{array}{l}\text { Visnjic Kastalli I., } \\
\text { Van Looy B. }\end{array}$ & 2013 & 23 \\
\hline $\begin{array}{l}\text { Living up to the value agenda: The } \\
\text { empirical realities of through-life } \\
\text { value creation in construction }\end{array}$ & $\begin{array}{l}\text { Construction } \\
\text { Management and } \\
\text { Economics }\end{array}$ & $\begin{array}{l}\text { Leiringer R., } \\
\text { Green S.D., } \\
\text { Raja J.Z. }\end{array}$ & 2009 & 20 \\
\hline $\begin{array}{l}\text { Buyer-supplier relationships } \\
\text { in a servitized environment: } \\
\text { An examination with Cannon } \\
\text { and Perreault's framework }\end{array}$ & $\begin{array}{l}\text { International } \\
\text { Journal of Operations } \\
\text { and Production } \\
\text { Management }\end{array}$ & $\begin{array}{l}\text { Bastl M., } \\
\text { Johnson M., } \\
\text { Lightfoot H., } \\
\text { Evans S. }\end{array}$ & 2012 & 17 \\
\hline $\begin{array}{l}\text { Concurrent and disconnected } \\
\text { change programmes: Strategies } \\
\text { in support of servitization } \\
\text { and the implementation of } \\
\text { business partnering }\end{array}$ & $\begin{array}{l}\text { Human } \\
\text { Resource } \\
\text { Management } \\
\text { Journal }\end{array}$ & $\begin{array}{l}\text { Raja J. Z., } \\
\text { Green S.D., } \\
\text { Leiringer R. }\end{array}$ & 2010 & 17 \\
\hline $\begin{array}{l}\text { Hybrid value creation: } \\
\text { A systematic review of an } \\
\text { evolving research area }\end{array}$ & $\begin{array}{l}\text { Journal fur } \\
\text { Betriebswirtschaft }\end{array}$ & $\begin{array}{l}\text { Velamuri V. K., } \\
\text { Neyer A.-K., } \\
\text { Moslein K.M. }\end{array}$ & 2011 & 14 \\
\hline $\begin{array}{l}\text { Servitization within manufacturing: } \\
\text { Exploring the provision of advanced } \\
\text { services and their impact on vertical } \\
\text { integration }\end{array}$ & $\begin{array}{l}\text { Journal of } \\
\text { Manufacturing } \\
\text { Technology } \\
\text { Management }\end{array}$ & $\begin{array}{l}\text { Baines T., } \\
\text { Lightfoot } \mathrm{H}_{.} \\
\text {Smart P. }\end{array}$ & 2011 & 13 \\
\hline $\begin{array}{l}\text { Making a profit with R\&D } \\
\text { services - The critical role of } \\
\text { relational capital }\end{array}$ & $\begin{array}{l}\text { Industrial } \\
\text { Marketing } \\
\text { Management }\end{array}$ & $\begin{array}{l}\text { Kohtamaki M., } \\
\text { Partanen J., } \\
\text { Moller K. }\end{array}$ & 2013 & 10 \\
\hline
\end{tabular}

Source: data from this research (2015). 
Table 2 presents the number of publications by journal, 7 publications in the 'Journal of Manufacturing Technology Management' and 6 publications for each in the journals 'Intangible Capital' and 'International Journal of Operations and Production Management'. It is important to note that the journal 'Journal of Operations Management' had only one result related to the term.

Table 2 - Number of publications per journal.

\begin{tabular}{ll}
\hline \multicolumn{1}{c}{ NUMBER OF JOURNALS } & N $^{\circ}$ OF PUBLICATIONS \\
\hline Journal of Manufacturing Technology Management & 7 \\
\hline Intangible Capital & 6 \\
\hline International Journal of Operations and Production Management & 6 \\
\hline Journal of Business and Industrial Marketing & 3 \\
\hline Service Business & 3 \\
\hline International Journal of Physical Distribution and Logistics Management & 3 \\
\hline
\end{tabular}

Source: Data from this research (2015).

Figure 1 shows the impact factor of the journals (factor $\mathrm{H}$ ), according to the Scimago (2015). The impact factor identifies the journals that have higher amount of significant material related to their topics of interest, establishing thus, the qualification of the journal (ARAUUJO, 2006). In Brazil, the classification of journals is through the extracts A1, A2, B1, B2, B3, B4, B5 and C, and journals classified as A1 has the highest qualification, while those classified as $\mathrm{C}$ are less qualified. According to the Triennial Evaluation of CAPES (2013), the journals that have $\mathrm{H}$ factor greater than 20 are considered equivalent to $\mathrm{A} 1$ extract. Thus, it is possible to understand that from the journals considered in this analysis, $87 \%$ are compatible with the most qualified journals in the national scenario, while $13 \%$ of the journals would be classified in A2 or B1 extracts, according to its factor $h$. 
Figure 1 - Impact Factor of Journals.

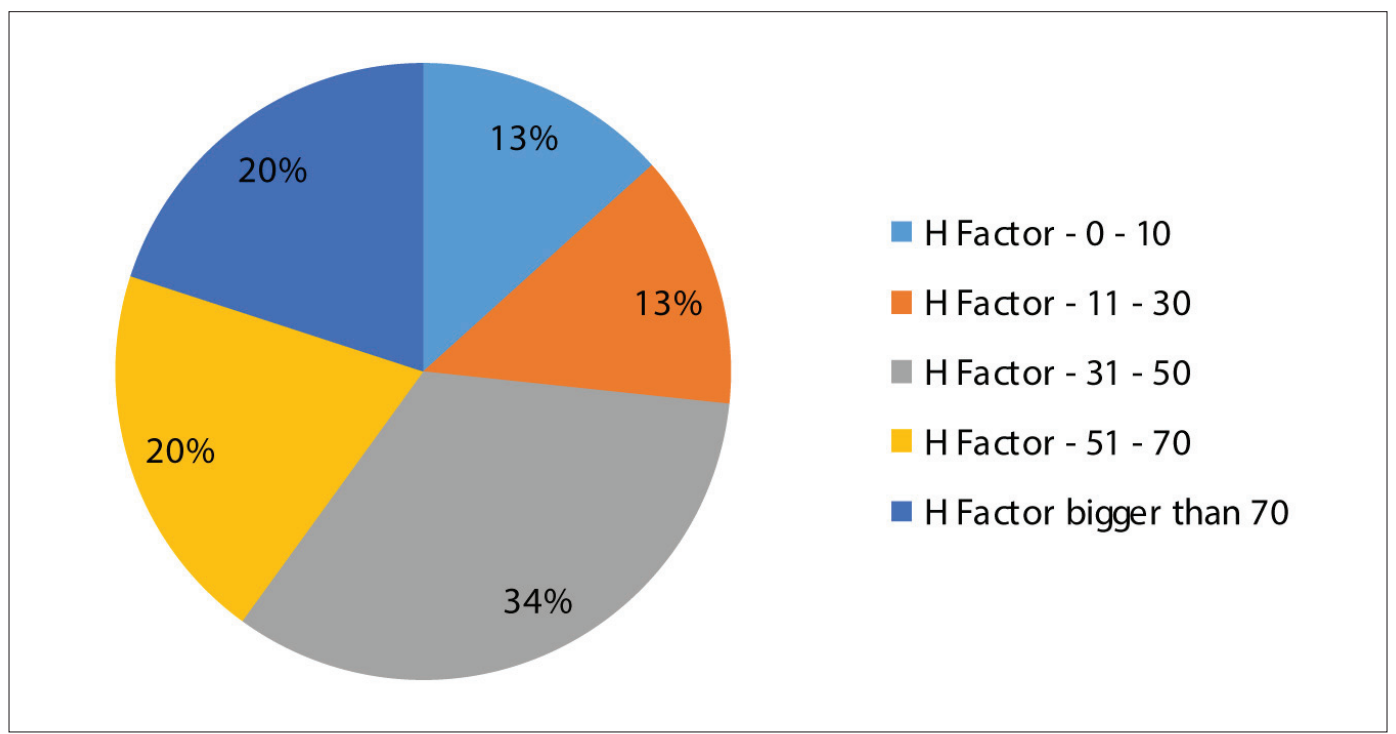

Source: Data from this research (2015).

This analysis allows the understanding that, although the number of citations be considered low, if related to other topics and other relevant areas within the administration, the qualification of journals is high. Thus, it is possible to understand that the articles have spread among a scientifically qualified public and has conditions to replicate or carry out further studies on the subject.

Table 3 shows the number of publications by country, taking into account the country's lead author. From this table you can see that the United Kingdom has the highest number of publications related to the theme servitization, followed by Finland and Spain. Brazil has only one publication related to the topic. The cutoff point defined by the authors was 10 countries.

Table 3 - Number of Publications per Country.

\begin{tabular}{cc}
\hline COUNTRY & No OF PUBLICATIONS \\
\hline United Kingdom & 25 \\
\hline Finland & 12 \\
\hline Spain & 10 \\
\hline
\end{tabular}




\begin{tabular}{cl}
\hline Sweden & 10 \\
\hline Italy & 7 \\
\hline United States of America & 5 \\
\hline Taiwan & 4 \\
\hline Australia & 3 \\
\hline Belgium & 3 \\
\hline Germany & 3 \\
\hline
\end{tabular}

Source: Data from this research (2015).

The number of publications per year (Figure 2) shows that, although the term servitization have been developed in 1988, more than 20 years have passed without that there were other publications related to the topic. In 2009, when the interest in the topic resurfaced, 5 articles were published, but the number increased significantly only in 2013 , when there were 17 publications. In the year 2014 there were also 17 publications and year 2015 has 13 publications. However, it is noteworthy that the data collection ended in July 2015, this way, the year has not been considered in its entirety.

Figure 2 - Publications per year.

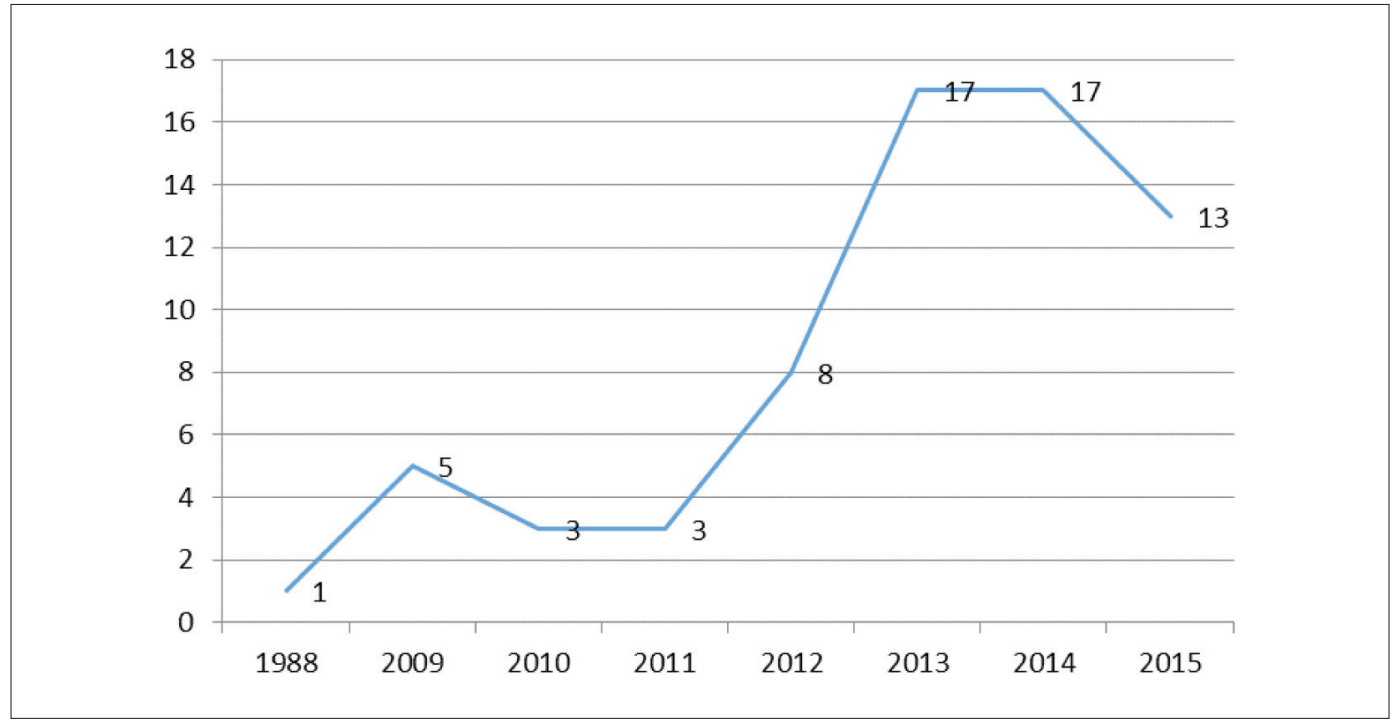

Source: Data from this research (2015). 
The number of publications by author shows that the author Howard W. Lightfoot, from the United Kingdom, is the author with the largest number of publications on servitization with 6 publications, followed by Tim S. Baines with 5 publications and Jawwad Z. Raja, also with 5 publications. Importantly, the authors Sandra Vandermerwe and Juan Rada, despite having developed the term servitization, have only one publication on the subject. The results are described in Table 4.

Table 4 - Number of Publications per Author.

\begin{tabular}{cc}
\hline AUTHOR & No OF PUBLICATIONS \\
\hline Lightfoot, $H$. & 6 \\
\hline Baines, $T$. & 5 \\
\hline Raja, J.Z. & 5 \\
\hline Johnson, M. & 3 \\
\hline Kowalkowski, C. & 3 \\
\hline Martinez, V. & 3 \\
\hline Neely, A. & 3 \\
\hline Raddats, C. & 3 \\
\hline
\end{tabular}

Source: Data from this research (2015).

Regarding the number of publications by education institution, the Cranfield University, located in the United Kingdom, has 11 publications, followed by the University of Cambridge, with 7 publications, also in the United Kingdom. Among the key words considered by the authors of each article, Table 5 shows the words that appear more often. The word 'servitization', the central theme of this research, was cited 49 times. The following cited words were 'Product-service systems' and 'manufacturing industries', respectively with 8 and 6 citations. The cutoff point used was 15 keywords. 
Table 5 - Keywords used more often.

\begin{tabular}{|c|c|}
\hline Keywords & $N^{\circ}$ of citations \\
\hline Servitization & 49 \\
\hline Product-service systems & 8 \\
\hline Manufacturing industries & 6 \\
\hline Service-dominant logic & 5 \\
\hline Supply chain management & 5 \\
\hline Integrated solutions & 4 \\
\hline Manufacturing & 4 \\
\hline Operations strategy & 4 \\
\hline Business model & 3 \\
\hline Capabilities & 3 \\
\hline Case study & 3 \\
\hline Industrial services & 3 \\
\hline Operations management & 3 \\
\hline Product-service system & 3 \\
\hline Service infusion & 3 \\
\hline
\end{tabular}

Source: Data from this research (2015).

Regarding the sector of analysis of the considered articles, these were identified from reading the abstracts of the articles. Thus, $43 \%$ of articles not made explicit, in their abstracts, the sector of analysis or constituted literature reviews. In addition, $8 \%$ of the articles analyzed manufacturing companies, while $3 \%$ of the articles analyzed B2B manufacturers, multiple sectors, publishers and also the IBM company was analyzed by $3 \%$ of the articles. The remaining $37 \%$ of the articles had several analysis sectors. These results are depicted in Figure 3. 
Figure 3 - Sector of Analysis of Articles.

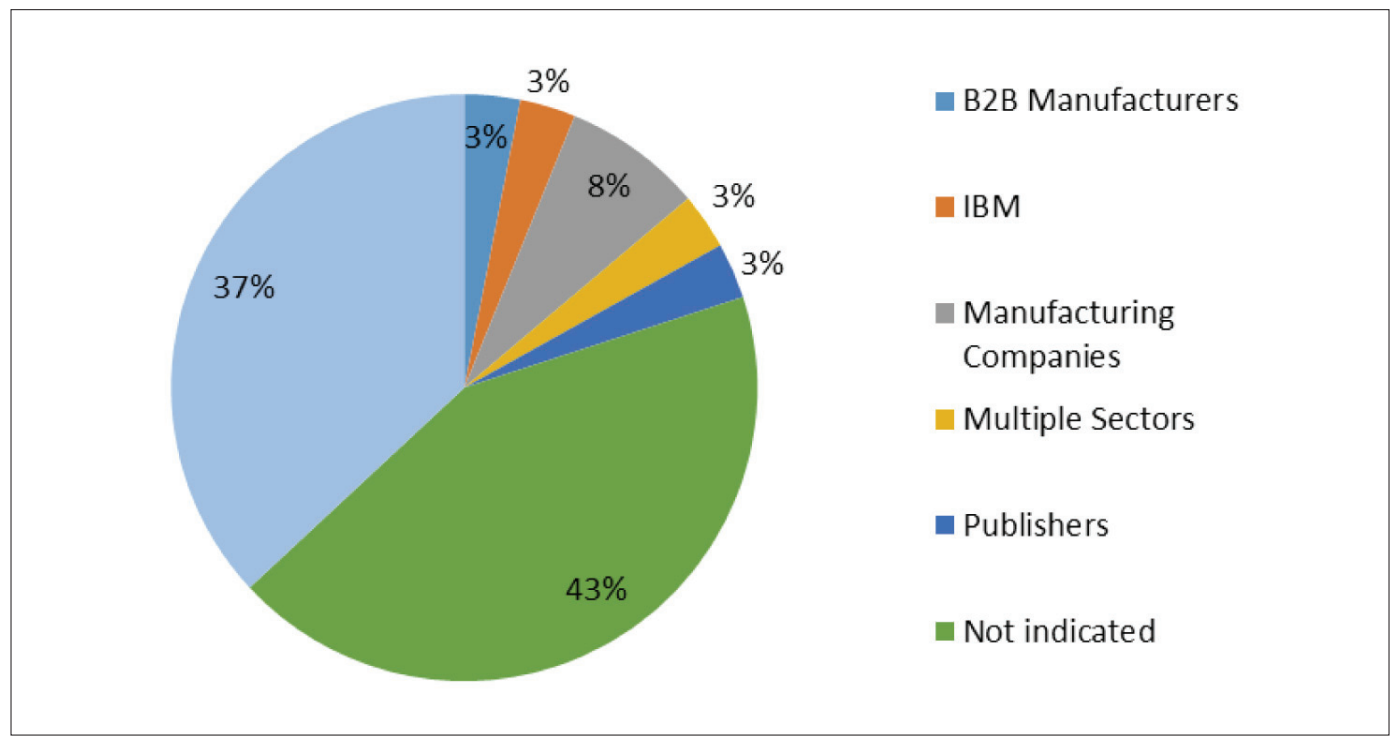

Source: Data from this research (2015).

With regard to the techniques used in the articles considered, $39 \%$ of the articles used case study. In addition, $12 \%$ of articles constituted literature reviews, $5 \%$ of the articles used surveys and $4 \%$ were theoretical frameworks. Moreover, $19 \%$ of the articles did not indicate the technique used in the abstract and $21 \%$ of the articles used other techniques.

Thus, as shown in Figure 4, it is possible to understand that $64 \%$ of the articles employed qualitative methods, while only $17 \%$ of the articles employed quantitative methods. Moreover, $19 \%$ of the articles did not report on their abstracts the method used.

Analyzing the future research suggestions from the articles published in 2015 , it was possible to identify the need for empirically testing the relations established trough the literature (LEONI, 2015; OPRESNIK; TAISCH, 2015; TUNISINI; SEBASTIANI, 2015). For example, as Leoni (2015) suggests trough a case study at IBM Corporation, it would be necessary to further investigate the relation between servitization and knowledge management at organizations. Also, as suggested by Opresnik and Taisch (2015), future research could focus in the Big Data exploitation as the next step for value creation after a manufac- 
turing enterprise has servitized its products, enabling manufacturers to revise their business models. Both papers highlight the importance of knowledge management being connected to operations management, in order to create value for organizations.

Figure 4 - Methods used in the articles.

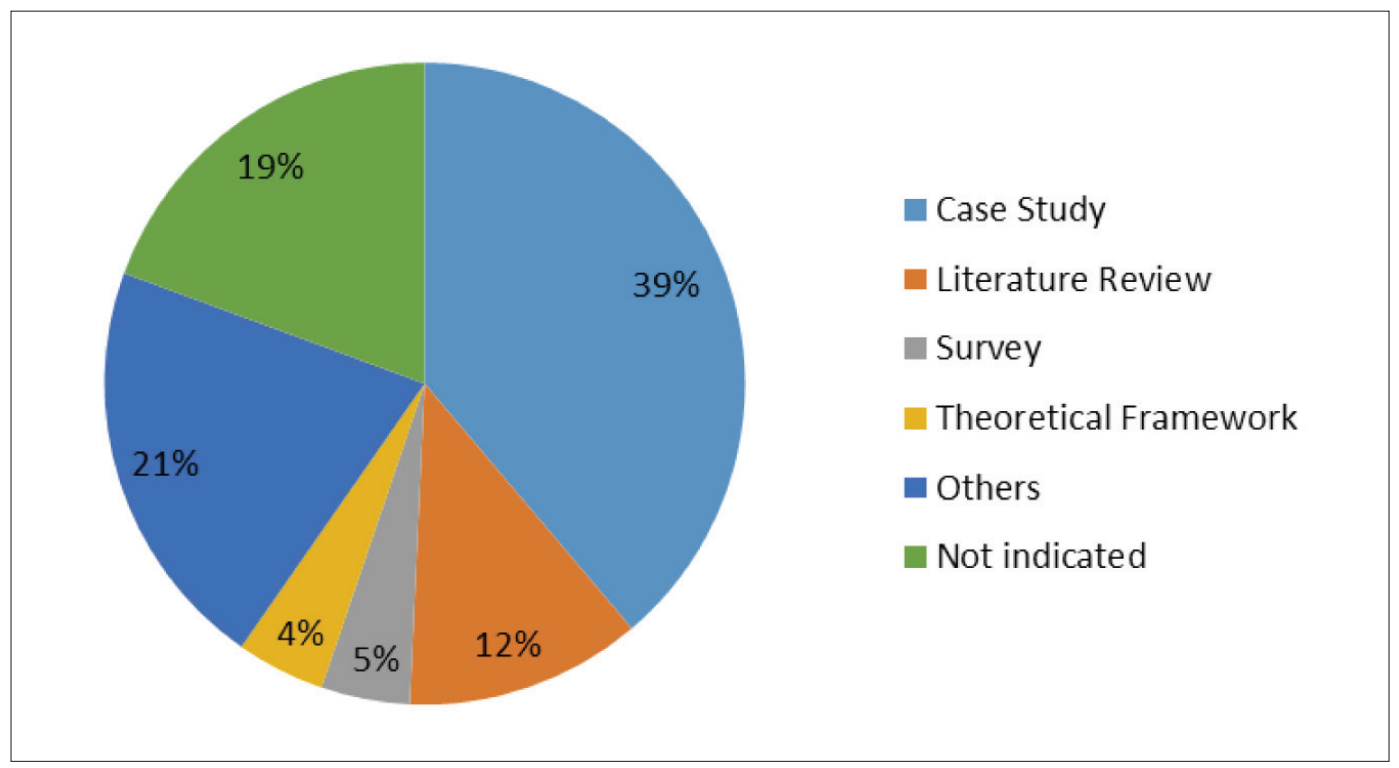

Source: Data from this research (2015).

The future research suggestions also emphasize the importance to relate the servitization processes to the customer satisfaction and both the customer and provider's performance. The development of these researches could help companies to build long-term commitment between the parties, through the servitization processes (TRKMAN et al., 2015).

\section{CONCLUSIONS}

This research had as main objective to explore the studies related to the term 'servitization', identifying the journals and authors with the highest number of publications, as well as the sector of analysis used in the field of Business, Management and Accounting. Therefore, it was conducted a survey in the Scopus database, which identified 67 articles that related the term in the title, abstract and keywords. 
From reading the abstracts of articles considered, it was possible to identify the involvement of 37 journals and 155 researchers from 22 countries researching the topic 'servitization'. In addition, it was noted that the term was developed in 1988, but most of the studies were carried out from the year 2013. From this result, it is possible to understand that the interest of companies and academy is changing through the last decades, and both are getting more interested in the product-service systems, instead of pure manufacturing companies.

Among the journals that have a higher number of publications related to the subject, it's possible to mention the 'Journal of Manufacturing Technology Management', 'Intangible Capital' and 'International Journal of Operations and Production Management'. These journals are European publications, two journals produced in the United Kingdom and one in Spain, with an impact factor between 05 and 86 , which allows classifying them as relevant publications in their areas of interest.

In addition, the identification of the country of origin of the authors, and the location of the institutions with the highest number of publications, added to the location of the journals, allows the understanding that the European countries have great interest and research on the servitization, since European countries are among the first places in the aforementioned analyzes. In addition to the UK, Spain and Finland have also carried out numerous studies on the subject.

Already in relation to the main sectors of analysis, it was noticed that most of the articles considered did not indicate on their resumes the sector of analysis or constituted literature reviews. Among others, it was noticed that most of the articles analyzed manufacturing companies, with attention also for B2B manufacturers, publishers, multiple sectors or IBM company. Thus, we identified a gap in the publications about the servitization, which would be the subject of analysis from the perspective of the end user.

Still, identifying the keywords most considered in the articles, it was possible to understand terms that can be considered similar to servitization, suggesting new fields of study, such as the terms 'service infusion', 'product-service systems', 'service- dominant logic' and 'Integrated Solutions', for example. Thus, it is possible to understand that some of the gaps related to the term servitization may have been filled with articles dealing with the same subject, however, using a different name. The results brought by this analysis corroborate results found by other authors, who suggest a difficulty of applying the concept due to a lack of unity in the nomenclatures used (BAINES et al., 2009b; ELORANTA; TURUNEN, 2015). 
In the same way, with respect to the methods used in the study, it was found that $64 \%$ of the articles analyzed were performed from a qualitative approach, with attention to the studies of single or multiple case. Another widely used method was a literature review, with some occurrences of theoretical frameworks and surveys. The analyzed papers suggest the need for developing scales that can evaluate the customer and provider performance, generated by servitization. Although the term servitization is being used since the 1980's, the main contribution of papers regarding the subject is theoretical, pointing to a lack of maturity on this issue.

The most recent studies considered in this paper emphasizes the importance of future researches that could empirically test the findings from the case studies or literature reviews. In addition, the studies suggest to relate the servitization paradox to other subjects and areas as marketing (through consumer satisfaction) and knowledge management, allowing the strengthening of the subject through its interdisciplinarity.

Limitations of this study lies in the fact that the survey considered only one database, which did not allow the identification of all articles related to the field. In addition, they considered only the complete articles published in journals, which did not allow an analysis of the publications in events regarding the subject. With regard to the theories used as a base for the articles considered, it was not possible to identify these from the readings of the abstracts.

The research contributions arise from the identification of gaps in the previous papers on servitization as an incipient amount of quantitative techniques in the articles, the absence of the final consumer perspective and a possible differentiation of results related to the topic in developed countries and countries in development. Moreover, it was possible to identify new terms which can constitute similar fields to servitization, and understand the need to associate the servitization paradox to other subjects, in order to fully understand not only the term, but mainly its importance in the contemporary world.

It is suggested the realization of new studies developed in other databases, as well as the addition of new terms related to servitization in these surveys. Still, it is suggested to conduct a systematic review of the literature using the articles considered in this research in order to understand the theories that may be related to servitization, in addition to conducting a survey that allows to understand the differences, if any, between the understanding of the term in developed and developing countries. 


\section{REFERENCES}

ARAÚJO, C. A. Bibliometria: evolução histórica e questões atuais de palavras num texto. Em Questão, v. 12, n. 1, p. 11-32, 2006.

BAINES, T.; LIGHTFOOT, H.; PEPPARD, J.; JOHNSON, M.; TIWARI, A.; SHEHAB, E.; SWINK, M. Towards an operations strategy for product-centric servitization. International Journal of Operations \& Production Management, v. 29, n. 5, p. 494-519, 2009a.

BAINES, T.; LIGHTFOOT, H.; BENEDETTINI, O.; KAY, J. The servitization of manufacturing: A review of literature and reflection on future challenges. Journal of Manufacturing Technology Management, v. 20, n. 5, p. 547-567, 2009b.

BRASÍLIA. COORDENAÇÃO DE APERFEIÇOAMENTO DE PESSOAL DE NÍVEL SUPERIOR - CAPES. Documento de Área 2013. Brasília: Capes, 2013.

CALDAS, M. P.; TINOCO, T.; CHU, R. A. Análise bibliométrica dos artigos de RH publicados no Enanpad na década de 1990: um mapeamento a partir das citações dos heróis, endogenias e jac- tâncias que fizeram a história recente da produção científica na área. In: Encontro Anual da Associação Nacional dos Programas de Pós-Graduação em Administração, 27, 2003, Atibaia, SP, Anais... Atibaia, SP, EnAMPAD, 2003.

COLLIS, J.; HUSSEY, R. Pesquisa em administração: um guia para alunos de graduação e pós-graduação. 2. ed. Porto Alegre: Bookman, 2005. 349p.

COOPER, R. B.; BLAIR, D.; PAO, M. Communicating MIS research: A citation study of journal influence. Information Processing \& Management, v.1, n. 29, p.113-127, 1993.

ELORANTA, V.; TURUNEN, T. Seeking competitive advantage with service infusion: a systematic literature review. Journal of Service Management, v. 26, n. 3, p. 394-425, 2015.

ELSEVIER. Scopus. Disponível em: <http://www.scopus.com/>. Acesso em: 05 jul. 2015.

FONSECA, Edson Nery da (Org). Bibliometria: teoria e prática. São Paulo: Cultrix, Ed. da USP, 1986. 
JIANG, X.; LI, S.; ZHANG, L. The Study on The Influencing Factors on Relationship Performance in Servitization of Manufacturing. In: INTERNATIONAL CONFERENCE ON INFORMATION MANAGEMENT, INNOVATION MANAGEMENT AND INDUSTRIAL ENGINEERING, 2009., Xi'an. Proceedings of International Conference on Information Management, Innovation Management and Industrial Engineering. Xi'an: Ieee, 2009. p. 480-484.

LI, J. H.; LIN, L.; CHEN, P.D.; MA, L., Y. An empirical study of servitization paradox in China. The Journal of High Technology Management Research, $v$. 26, p. 66-76, 2015.

LEONI, L. Adding Services means adding knowledge: an inductive single-case study. Business Process Management Journal, v. 21, n. 3, p.610-627, 2015.

LI, J. H. et al. An empirical study of servitization paradox in China. The Journal of High Technology Management Research, v. 26, p. 66-76, 2015.

MAlHOTRA, N. K. Pesquisa de marketing: foco na decisão. 3.ed. São Paulo: Pearson, 2011. xx, $491 \mathrm{p}$

MEADOWS, A. J. A comunicação científica. Brasília: Briquet de Lemos Livros, 1999.

NEELY, A. Exploring the financial consequences of the servitization of manufacturing. Operations Management Research, v. 1, n. 2, p. 103-118, 2009.

OLIVEIRA, M. M. Como fazer pesquisa qualitativa. Petrópolis, Vozes, 2007.

OPRESNIK, D.; TAISCH, M. The value of Big Data in servitization. International Journal of Production Economics, v. 165, p. 174 - 184, 2015.

PAWAR, K. S.; BELTAGUI, A.; RIEDEL, J.C.K.H. The PSO triangle: designing product, service and organisation to create value. International Journal of Operations \& Production Management, v. 29, n. 5, p. 468-493, 2009.

SCHMENNER, R. W. Manufacturing, service, and their integration: some history and theory. International Journal of Operations \& Production Management, v. 29, n. 5, p. 431-443, 2009.

SCIMAGO JOURNAL \& COUNTRY RANK. Journal Search. Disponível em: $<$ http://www.scimagojr.com/journalsearch.php>. Acesso em: 10 ago. 2015. 
SMITH, L.; MAULL, R.; NG, I. Servitization and Operations Management: a Service Dominant-logic Approach. International Journal of Operations \& Production Management, v. 34, n. 2, p. 242-269, 2014.

TAGUE-SUTCLIFFE, J.. An introduction to informetrics. Information processing \& management, Oxford, v. 28, n. 1, p. 1-3, 1992.

TELLUS INSTITUTE. Servicizing: The Quiet Transition to Extended Product Responsibility. Tellus Institute, Boston, 1999.

TRKMAN, P.; MERTENS, W.; VIAENE, S.; GEMMEL, P. From Business process management to customer process management. Business Process Management Journal, v. 21, n. 2, p. 250 - 266, 2015.

TUNISINI, A.; SEBASTIANI, R. Innovative and networked business functions: customer-driven procurement. Journal of Business \& Industrial Marketing, v. 30, n. $3 / 4$, p. $302-311,2015$.

VANDERMERWE, S.; RADA, J. Servitization of business: Adding value by adding services. European Management Journal, v. 6, n. 4, p. 314-324, 1988. 